Journal Home Page:

http://perlinguam.journals.ac.za

\section{Per Linguam}

A Journal for Language Learning Tydskrif vir Taalaanleer

\title{
LITERACIES: SKILLS AND PRACTICES IN DEVELOPING WRITING IDENTITY
}

\author{
Verbra Pfeiffer \\ Stellenbosch University
}

'Freeing yourself was one thing; claiming ownership of that freed self was another.' Toni Morrison (1987: 95)

This study was prompted by the fact that students who use a second language (L2) for higher education studies are often faced with the dilemma of not being able to express themselves in writing. This study attempts to comprehend experiences by higher education multilingual students engaging in the practice of expressive writing. Mastering a language and being able to make sense of oneself in writing is a complex activity especially for L2 writers. In this article, I look at ways in which we may understand the writing process better when viewing students' writing against the backdrop of multilingualism in South Africa, with the notion of a social (cognitive) process and its influence on their ability to write. The literature review highlights Bakhtin's concept of a heteroglossic dialogic relationship referring to the tensions between the multiplicities of language varieties within a national language, which draws it towards a standard central version by the use of expressive writing. This qualitative case study design, guided by interpretive epistemology, was used to collect students' views, perceptions and suggestions on their experiences in writing. The aim of this study was to identify the kinds of strategies that could assist L2 students with English language writing tasks. The findings suggest that multilingual students benefit from the use of expressive writing. When pondering the holistic view of these findings, this study endorses the use of expressive writing as a developmental tool in the process of becoming academically literate.

Keywords: literacy pedagogy, expressive writing, multilingualism, cognitive challenges, academic literacy, heteroglossia.

\section{INTRODUCTION}

This study focuses on expressive writing, which I have defined as making a connection between the known and new on paper. It may also be seen as writing for the purpose of displaying knowledge or supporting self-expression (Graham \& Harris, 1989; Pfeiffer, 2015; Russell, Baker \& Edwards, 1999). I use this form of writing to help students find their sense of being, to aid them in their academic writing. With expressive writing, multilingual students may develop a fluency in their academic writing because they need to include multiple discursive practices. Garcia (2009: 45) points out that multilingual students do not develop mirror competencies in all their languages. Their language use is not like a bicycle, but 'more like an all-terrain vehicle whose wheels extend and contract, flex and stretch, making possible, over highly uneven ground, movement forward that is bumpy and irregular but also sustained and effective' (Garcia, 2009: 45). This could imply that multilingual students will experience less difficulty taking on the challenges of communicating in a language that is not their mothertongue and they will strive to overcome hurdles by learning new words and trying to make sense of what they read, using their other languages as resources. 
Very often, universities use set coursebooks which present themselves as fact-based and transference-based models of teaching and learning (Garcia, 2009). As a result, there is little or no scope for the teacher or the students to reclaim their own language when it is different from that of the textbook. Makalela (2014: 670) argues that the outcome in such instances is that neither the teacher nor the students have the opportunity to reformulate their language because second language (L2) students are forced to engage with texts in the language of that text, which may not be their first language (L1). They are therefore not always able to reformulate because they may have a weak grasp of the L2. What Makalela (2014) implies is that we need to look at multilingual students in a different way, because if we force them to use only the language of instruction, they are bound to parrot what they find in the textbooks.

Hence, the teaching and learning of language fails to develop into critical and creative consciousness in the classroom. This article aims to investigate the use of expressive writing by means of autobiographical writing and journal writing in a Communications classroom. This article aspires to generate an understanding of the strong relationship between the teaching of language, and teaching students whose mother tongue is English and students whose mother tongue is not English, thereby illustrating how the recognition of the varied ways in which language is taught could offer benefits to the classroom (Brumfit \& Carter, 1986; Pfeiffer, 2015). This article also looks at the scope provided by expressive writing to engender provisional interpretations through writing which can bring about constructive educational and social change. The rationale for my investigation is to use expressive writing in more than one language to improve academic writing in only one language.

\section{LITERATURE FRAMEWORK}

Although it is important for classroom-based studies to investigate how students learn to write in a second language, it is equally important to learn how students learn a second language through writing (Harklau, 2002; Pfeiffer, 2015). What we most commonly think of as academic writing is the activity of producing text to be read by other academics. For example, writing articles, assignments or essays (Harklau, 2002) can be seen as academic writing where the author meets the standards for spelling, grammar and other rules of academic communication. Besides 'formal' academic writing, there is also journal or autobiographical writing where the writer is the sole audience and, here, the formal rules may be relaxed. As discussed in Pfeiffer (2015), such writing can serve as a stepping stone to formal, academic writing.

In light of this, our writing is influenced by our life histories. Consequently, each word we write represents an encounter, possibly a struggle, between our multiple past experiences and the demands of a new context (Ivanic, 1998). Writing is not some neutral activity which we just learn like a physical skill, but one which implicates every fibre of the writer's multifaceted being (Ivanic, 1998: 181). With journal and autobiographical writing, the word 'becomes "one's own" only when the speaker populates it with his own intentions' (Middendorf, 1992: 35). The implication here is that our discourse is ourselves. However, opposing forces are at work within human discourse and human society (perhaps human consciousness itself). What this implies is that consideration of a writer's roots and the knowledge that his/her identity brings may be viewed as socially constructed and hence constantly changing in the same way the consequences of his/her life's history develop (Ivanic, 1998: 181). When this struggle is healthy and not lopsided (in the sense of the writer's identity), heteroglossic awareness is at its most potent. This Bakhtinian key is of vital importance in the modern classroom. Heteroglossia is the coexistence, combination, alternation and juxtaposition of ways of using the communicative and expressive resources that language/s offer us (Leppänen, Pitkänen, Piirainen-Marsh, Nikula 
\& Peuronen, 2009: 1082). Therefore, language learning should be seen as a human activity for facilitating personal expression and reflection. With this purpose, Lapidus, Kaveh and Hirano (2013), and Park (2013a, 2013b) explored autobiographical writing as a method for constructing L2 identity, which this study explores.

Students often find it difficult to translate from one language to another since they lack experience and chances for academic conversation where concept formation and logical thinking are developed in their L1 and L2. The problem that we are currently facing in South Africa is that, because we have this multilingual array of students from different races and backgrounds who do not all have the same mother tongue, the teacher is left with the daunting task of not being able to translate the work given in class to all students in their native languages.

Garvin (2013: 77) argues that, in order for students to be able to draw on their L1 to express themselves in the L2, they need to be taught the basic language skills of transferring knowledge between languages to enable them to translate cognitive knowledge. Garvin cautions that, unless this is done, their creativity will be crushed. Thus, students need to develop their L1 and L2 competency in writing. Accordingly, L2 writers struggle to maintain the lexical and structural constraints aiming at producing what sounds like an English text, while writers' imagination, self-expression and creativity are avoided (Garvin, 2013: 78). When activities are designed that encourage creativity within reasonable subject-related constraints, students are led to empowerment and ownership of their own learning (Nunn, Suvasubramaniam, Guefrachi, Tariq \& Al Shami, 2012: 7). It is at this juncture that students' identities may be displayed in their writing.

Creating an identity for L2 students can often be very challenging, maybe even difficult, due to the expectations of the subject teachers who present students with new disciplines. At this point, I argue that the author's appearance in the text may be explicit or absent where the opportunity to create a plausible academic identity and a voice with which to present an argument might not be visible (Ivanic, 1998: 48). We should not simply assume that academic writing is universally impersonal because we could disguise variability and prevent our students from coming to terms with the specific demands of their disciplines. In addition, Hyland (2002: 353) argues that, instead of equipping learners with the linguistic means to achieve their rhetorical invisibility, we need to guide them towards an awareness of the options that academic writing offers.

With this purpose in mind, Ivanic (1998: 24) addresses three aspects of writer identity: the 'autobiographical self' delineates writers' sense of their roots; the 'discoursal self' 'is the impression - often multiple, sometimes contradictory which [a writer] consciously or unconsciously conveys of themselves in a particular written text, [relating] to values, beliefs and power relations in the social context in which they were written'; and the 'self as author' is a relative concept which 'concerns the writer's "voice" in the sense of the writer's position, opinions and beliefs'.

This identity construction is significant in discussions of academic writing since 'writers differ considerably in how far they claim authority as the source of the content of the text, and in how far they establish an authorial presence in their writing' (Ivanic, 1998: 26). Consequently, these identity constructions can further raise our awareness of how English and its culture have become a critical component in the academic and professional development of all language learners and users (Park, 2013). In a class of multilingual speakers, students have to shuttle between different spaces of self when they articulate thoughts in different languages 
(Canagarajah, 2011; Makalela, 2015). For multilingual communication to run smoothly, languaging is an integral part of identity construction, which means that languaging experience represents negotiating identities that are multiple and fluid (García, 2011). Given the multilingual spaces to express complex meanings, these speakers decide who they want to become (Makalela, 2013, 2015). This multilingual space referred to here may be viewed in the students' journal writing, which is looked at in the research instruments section.

With regard to the 'self as author' identity (Ivanic, 1998: 26), an expressive writing instruction was designed to assist students in their writing. My intention with the use of expressive writing instruction was originally to free students from the shallow 'performance' (Spigelman, 1996: 130) that was current-traditional exposition, where they just wrote enough to be accepted at university. Now, instead of performance, 'true and honest narratives' were required of them (Spigelman, 1996: 130). One cannot really see through someone else's eyes, but through writing and reading one may be able to get close enough to appreciate the richness of another's vision. Consequently, Garcia (2009: 45) sees this discursive practice as ideologically desirable for multilingual students and their languaging practices as part of the decisions about who they want to become. Therefore, students articulate their thoughts and make strategic choices that are situation-sensitive in order to achieve their communicative goals (Makalela, 2015).

This study hopes to offer some verifiable explanation to demonstrate the assumption that, when students actively use expressive writing for independent learning and for discovering interrelationships among their own reading-writing-thinking practices in more than one language, the thinking processes of the writer complement the reader's reception of the material (Pfeiffer, 2015). With this purpose in mind, the above-mentioned demonstration could instil a growth in power and effectiveness when the reader and writer can complement each other.

\section{METHODOLOGY}

This study was designed to describe qualitatively as well as impressionistically the kinds of writing processes and strategies that the students went through in class, as well as the outcomes arising from their writing in multilingual contexts. This study was conducted at a tertiary institution in the Western Cape and consisted of 14 participants from South Africa and other parts of Africa (Ghana, Congo, Rwanda, Nigeria and Eritrea). The reason for the 14 participants was that they were the only students interested in improving their writing skills and participating in this study. I had received ethical clearance from the university where I collected the data as well as the University of the Western Cape. Table 1 below indicates each participant's country of origin and level of English.

Table 1: Participant information

\begin{tabular}{|c|c|c|c|c|c|}
\hline Student & $\begin{array}{c}\text { Country of } \\
\text { origin }\end{array}$ & $\begin{array}{c}\text { Time in South } \\
\text { Africa }\end{array}$ & $\begin{array}{c}\text { English at } \\
\text { high school }\end{array}$ & $\begin{array}{c}\text { L1, L2 or } \\
\text { EFL }\end{array}$ & Home language \\
\hline 1 & South Africa & Always & Yes & L2 & Afrikaans \\
\hline 2 & South Africa & Always & Yes & L2 & Afrikaans \\
\hline 3 & South Africa & Always & Yes & L2 & IsiXhosa \\
\hline 4 & South Africa & Always & Yes & L1 & English \\
\hline 5 & South Africa & Always & Yes & L2 & French \\
\hline 6 & $\begin{array}{c}\text { Congo } \\
\text { Brazzaville) }\end{array}$ & 2 years & Yes & English \\
\hline 7 & South Africa & Always & Yes & L1 & IsiXhosa \\
\hline 8 & South Africa & Always & Yes & L2 & IsiXhosa \\
\hline 9 & South Africa & Always & Yes & L2 & \\
\hline
\end{tabular}




\begin{tabular}{|c|c|c|c|c|c|}
\hline 10 & Nigeria & 3 years & Yes & EFL & Yoruba \\
\hline 11 & $\begin{array}{c}\text { Congo } \\
\text { (Brazzaville) }\end{array}$ & 2 years & Yes & EFL & French \\
\hline 12 & Rwanda & 6 years & Yes & EFL & French \\
\hline 13 & Ghana & 5 years & Yes & EFL & French \\
\hline 14 & South Africa & Always & Yes & L2 & IsiXhosa \\
\hline
\end{tabular}

As seen in Table 1, only two of the participants were English first language speakers and the rest were either English second language speakers or English foreign language (EFL) speakers. The length of time that the EFL speakers had been living in South Africa gave me some indication as to how much exposure they had had to English. Even though Students 12 and 13 had been living in South Africa for a number of years, it was quite interesting that they were aware that their English writing was problematic.

The context of my study was a text-based instruction programme which I taught to all first-year students where I incorporated elements from an integrated language arts approach. By using this approach, I integrated reading, writing, listening, speaking and viewing, as well as making sure that all students were involved in the tasks and class activities. Furthermore, I would provide the students with texts in class which they had to read, discuss and write about. My study spread over a semester to assist students in improving their academic writing technique. The text-based instruction programme that I implemented in the undergraduate wing of the faculty is the mainstay of my study. The purpose was to determine the centrality of a text-based instruction approach to L2 students and to determine whether an approach such as this can address the apprehension experienced by L2 users of English at a tertiary institution in Cape Town and whether it could have general implications for other South African universities. The L2 apprehension referred to here manifests itself in symptoms such as rote learning, little or no inclination to read or write, exam-oriented learning habits, poor motivation to attend and participate in Communications class, and increasing failure rate. This study seeks to show how multilingual students have the tenacity to recreate themselves by not using very common forms of communication in and outside the classroom at university level.

My research questions were:

- How did expressive writing create a space for the students to represent their identities?

- How can expressive writing improve their language skills?

- How can students write more expressive/responsive and communicative texts?

The students were advised to keep journals and record their daily experiences, which they wrote in English. The students created an autobiographical writing piece based on their lives, which could be interpreted as a personal response. This form of writing may be an intimidating form of writing, but also a liberating one - it is always profoundly generous, demonstrating one's willingness to share something of oneself (Voit, 2009). I decided to use these two styles of writing so that the students would not feel threatened when writing in a journal or even writing a personal autobiography. These two writing styles gave students the exposure to writing for different audiences. For example, with the journal writing, the students were not writing for an audience - even though I read it, it was personal. With the autobiographical writing, however, the students were given a sense of writing for an audience.

Before data collection, I conducted interviews with my students and it should be noted that the answers given by the students are verbatim dictations of what they said to me. For my interviews, I used a diagnostic assessment tool that allowed for 'meaningful interpretations and Per Linguam 2018 34(1):60-76 
fair use of results' with a few to, as Jan (2008:117) insists, improve instructional design and for guiding students' learning. The interviews were conducted to give me some indication as to which areas in their writing needed to be improved, how familiar students were with writing in journals and which writing exercises they needed to help them improve their academic writing.

In this article, I focus on whether the students actually wrote expressively and personally. This focus was my guide to look at examples in their writing where the students made use of their home language to emphasise the personal nature of their writing. Thus, for the journal entry, they were not given a grade, but for the autobiographical writing a holistic grading scale was used, which can be seen in Addendum 1. This grading scale gave me some reflection on how they were writing, and I could then evaluate whether they were meeting the demands of the audience.

In terms of the pedagogical framework, writing was not intended to be a language practice activity, but rather to become a 'kind of self-making or forming' (Van Manen, 1989: 238) endeavour.

\section{RESEARCH INSTRUMENTS}

\section{First interview}

As mentioned in my methodology, I conducted interviews with my participants before data collection, which also served as my diagnostic assessment to guide me in redesigning my instructional approaches, evaluate instructional resources and remediate students' weaknesses (Jan, 2008). With this purpose, I had a better idea of the students' understanding of the term 'expressive writing' as well as determining problems that they were experiencing in writing and ways in which I could assist them in their writing. Due to word limitation, I decided only to include three students' views on selected interview questions which I thought were pertinent for this article. Below I have included the questions and answers of the students.

\section{Define your understanding of the term 'expressive writing'.}

Student 1: $\quad$ The thought you have, you like to have and your imagination through it.

Student 2: $\quad$ To think fast. To think what is asked.

Student 3: $\quad$ It's a free way of thinking and expressing yourself.

As can be seen in the answers of Students 1 and 2: 'The thought you have ...' and 'To think fast,' these students did not quite have an understanding of expressive writing. Student 3 had a better understanding of what expressive writing is when he said: 'It's a free way of thinking and expressing yourself.' By asking this question, I wanted to find out before I conducted my study whether the students were familiar with the term 'expressive writing'. Most of the students gave a reasonable response on their understanding of what expressive writing was. Hence, this question gave me some indication as to which direction my research was to unfold as well as the way in which I could help students become familiar with the term expressive writing.

\section{What importance do you place on expressive thinking in English Studies? Why?}

Student 1: $\quad$ It's important because you are dealing with people. The way you want people to view you. 
Student 2: $\quad$ It's important so that people can express themselves, so that you know what you want to say and that you know what they mean.

Student 3: $\quad$ In writing one can express oneself better than in speaking. Speaking you have to consider the person. In writing you let your feelings flow and write to your heart's content and not based on the way the person looks or judge you. That's your own person bring across yourself.

In should be noted that, before I asked this question, I had explained the meaning of the question to the student. However, we notice that Students 1 and 2 did not understand the question, if we look at their answers: 'It's important because you are dealing with people' and 'It's important that you understand the way to take instructions and interpret it.' Student 3 understood the question the best and answered: 'It's important so that people can express themselves ....' The students had some idea that their feelings were involved when addressing expressive writing, but I am not sure they could make a definite connection as to how it would affect their writing.

\section{Have you done expressive writing at high school?}

Student 1: $\quad$ Yes.

Student 2: $\quad$ No.

Student 3: $\quad$ Yes.

If the students never really understood what expressive writing was, then I am not entirely sure that they practised this form of writing at school. Most of the students responded to the question. My impression was that it was not really a term that had been used at school.

\section{Did you have any problems in your writing exercises? What are the problems?}

Student 1: $\quad$ Problems with understanding and interpreting my writing. Understanding of words, spelling, pronunciation of words. Sometimes the sentences. Can't make a complete sentence. Difficulty summarizing in own words. Speaking French confuses me, then don't have the words in English.

Student 2: $\quad$ Language problems. How to use grammar and vocabulary neatly. How to use punctuation. How to structure essays neatly. How to work professionally.

Student 3: $\quad$ Punctuation problems. Spelling problems. Don't have problems in expressing myself in writing. Feel I can express myself better in writing than speaking.

The response to this question was particularly interesting because these answers were my guide as to what writing exercises could assist the students in improving their academic writing. Besides journal entries and autobiographical writing, I gave the students grammatical worksheets to work through on their own at home. It should be noted that these worksheets were never corrected, but were just meant to help them with some possible grammatical problems which could assist them in their writing.

The data analysed in this segment were meant to give me some indication as to what the students understood about expressive writing and how they would like to improve their writing. This segment also indicated the strength of the students' intuition and beliefs about their own ability to recognise, explore and nurture their abilities in writing.

\section{Journal entry}

Per Linguam 2018 34(1):60-76

http://dx.doi.org/10.5785/34-1-741 
Now I look at excerpts from the student's journal entries. My interest in their journal entries was stirred by the fact that I was trying to understand my students' journals as a space where I focused on whether they actually wrote expressively and personally. As mentioned in my methodology section, it was at this juncture that I was led to focus on examples where the use of other languages appear to emphasise the personal nature of their writing.

Student 1: $\quad$ I didn't do my presentation maybe I'll be the first one tomorrow, so I have to get there early, because my lecture is very strict. I don't blame her infect because she is trying by all means to teach us a punctuality because it is very important.

Student 2: $\quad$ I went to collect my journal from Ms or Mrs Pfeifferv. The reason for the "or" is because I don't know if she is married or not. This reminds me of Valentinesday when she "interrogated" me about my plans for the day and I replied by asking her if she was willing to take me out for lunch. Where I got the strength to ask that, "U weet allen" as the afrikaaners would say.

Student 3: $\quad$ I was one of the unpriviled kids born in a family where parent are incapable of looking after them. I grow up moving from a family member to the other, trying to fit into other people's home because my parent never gave me one. Growing up was like climbing mount Ever-Rest a million times without reaching the top.

The journal entries presented above suggest that the students made a definite attempt to express themselves freely with aspects relating to everyday living, where they wrote about their hopes, fears, joys, doubts, intuitions and initiations. Because of the many spelling and grammatical mistakes in their writing, I am inclined to believe that they expressed themselves freely because they were not afraid to write how they felt and also they were not anxious that I was going to read what they wrote. An example of this is seen with Student 3 when he writes: 'I was one of the unpriviled kids born in a family where parent are incapable of looking after them.' I did not get the impression that there was any superficial involvement in the students' writing. They wrote in first person and they paid no attention to grammar and punctuation errors.

We also notice clear code-switching taking place when Student 2 writes: "Where I got the strength to ask that, "U weet allen" as the afrikaaners would say.' This form of writing does not occur often in my research, but what I found most captivating was a perfect example of multilingualism because this student was actually isiXhosa and included some Afrikaans writing in his journal entry which was in English. This example also illustrates the manner in which this student 'moves' back and forth between two languages available to him in order to construct his understanding.

Below I have included four students' excerpts from another journal entry. Below, Student 1 portrays brutal honesty and his view on 'black students':

Student 1: $\quad$ buying food every month or even worse you can runout of food in the middle of the month, buying expensive bus tickets, adjusting to the environment, language barrier you quickly have to learn other people's languages I know you become multilingual but I think its more fun and interesting when you speak you own language, I think that might be a reason why most black students (not trying to sound racist) fail to part orm well or live to the standard of their progress report because we or feel we 
fail to get the rhythm going because of the expression but its not anyone's fault.

In this excerpt, the student expresses his view that being multilingual is an advantage, and he feels that speaking in his own language is 'more fun and interesting'. I view this form of L2 writing as meaningful literacy which can enhance learners' understandings:

About themselves, about the presence of others, and the diversity of thought and experience that are so much part of this world which means that, learning a language is about widening one's expressive resources and positioning oneself in multicultural and multilingual world (Hanauer, 2012: 10).

Student 2: $\quad$ Once I arrived by his place, I was surprised to see one of my old friends. It was been a longtime without seeing him. His name is Mathias. Cannot even remember the last time I saw him. I think, it can be more than ten years. After we conversated for such a long time, He told me that him and his family travelled to USA in 1999.

In this excerpt of Student 2, it is clear that he has another academic language at his disposal. Here the student demonstrates direct translation from French to English when he writes: 'It was been a longtime ...', which reads in French 'il a été fait longtemps...'. He uses the verb 'to be' to form the past tense rather than 'to have'. In this instance, the student is not aware that his writing is incorrect. Even though his writing is comprehensible, very often these are the kinds of mistakes that the students make when they are conducting direct translation.

Student 3: $\quad$ Today has set the pace for this whole term. I can tell now already it is going to fly by; but I'm quite prepared for anything coming my way. Eish! I forgot to go fetch my exercises from Ms Pfeifferv.

In this example, we see code-switching taking place when the student includes: 'Eish!' His sentence structure is immaculate and use of punctuation is correct.

Student 4: $\quad$ My answers were so quickly. I said finding a job. My preference of where I want to work is here in South Africa, just for trois of four years.

Again we notice code-switching taking place when the student writes: '... trois of four ...'. Knowing that he is writing in a journal, the student pays no attention to his writing and instead of writing 'three' he writes 'trois' in French. The aim of the journal entry was to allow the students the opportunity just to write in English and not pay any attention to writing structure, but at the same time develop a love for writing.

\section{Autobiographical writing}

Now I present some excerpts from the autobiographical writing. For this writing task, the students were given the opportunity to create a mind map, make notes for themselves or create a rough draft before handing in the version seen below. It should be noted that, due to word restriction, I have only included part of the autobiographical writing. Due to student confidentiality, I have used 'anonymous' where names should appear. 


\section{Student 1: $\quad$ I wish I knew my father}

My life was not easy to be born without a father by myside. My mother was there for me yet I needed my father. Growing older without a male in our house becomes a big challenges to me. In 1999, on November at the age of 8 it was the first time I live in the house that rules by a man. I startet call any man I see around me a father to me. I never wanted to question my mother whose my father, because I thought she has the reasons why she never told me about him.

\section{Student 2: $\quad$ My Uncle Christian}

In 2011, when I came in South Africa, my uncle gave me a gift and told me to be serious with my studies. He was doing his last year in the faculty of medecin in Lubumbashi. Tow month later my father called me, and asked me if I really love uncle Christian. I answered the question by yes, I do love uncle Christian. My father took a couple of minute to continue our conversation. He told me that something bad had happened, and uncle Christian passed away.

\section{Student 3: $\quad$ Never forget you Dad}

My name is Anonymous, born in DRC. I was born in a kingdom family, my father Anonymous was a kind in our village. He had 7 wives and my mother Anonymous known by the name of Anonymous. Bint means the fourth wives of king Anonymous. I am the youngest in our family, when I was born in August 1992 my father told his wives and family that they must call me Anonymous. In our culture Evo means 'my heart'. My father did loves me too much, I was everywhere with him, he never leave me alone.

The excerpts presented above are from three students who are not South Africans. In higher education, not only do we deal with South African from various language backgrounds (11 official languages), but we also have to deal with students from various parts of Africa, which means that educators have to cater for a larger variety of students. It may be true that, very often, foreign students do not have much exposure to English lessons at their schools in their home countries, hence they only get to learn English in the country where they are doing their tertiary education (South Africa). Consequently, in their writing there are clear signs of codeswitching when Student 3 writes: 'did loves me too much...' translated directly from French 'M'aiment trop'. In English, we write 'did love me...' or 'loved me ...'. Here, the student generalises the formation of the past perfect to the past definite. We notice that Student 2 spells the word 'medecin' the French way. In this instance, I do not think that the students are consciously aware of the mistakes that they are making in writing. With this in mind, this form of expressive writing is meant to enable students to write with confidence and, in due time, these kinds of spelling mistakes should become minimal.

Writing about personal things was not an easy task for the students to engage in, but they took on the challenge. For most of them, this was the first time that they had undertaken autobiographical writing about themselves, as indicated in the responses they gave in the first interview to the question as to whether they had ever written an autobiography. I noticed a flow in their sentence structures, with minor spelling, grammatical and punctuation mistakes. For example, Student 1 writes: 'My life was not easy to be born without a father by myside. My mother was there for me yet I needed my father.' These are simple sentences, but they make sense. If we look at the way the student started writing her/his essay, the confidence in writing is evident in their opening line, which captures the attention of the reader. The comma is missing, but there is a better understanding of the sentence. I detect a definite flow in the sentences with the use of conjunctions, like 'yet' from Student 1: 'My life was not easy to be born without a father by myside. My mother was there for me yet I needed my father.' Student 2: 'In 2011, when I came in South Africa, my uncle gave me a gift and told me to be serious 
with my studies. He was doing his last year in the faculty of medecin in Lubumbashi.' Student 3: 'My name is Anonymous, born in DRC. I was born in a kingdom family, my father Anonymous was a [king] in our village.'

\section{Second interview}

After extensive work with the students, I conducted a second interview to find out what they thought of the writing exercises that had been done with them to improve their writing. Below I have included some of the responses of the students.

\section{How did you feel about the writing exercises?}

Student 1: $\quad$ The writing exercises helped me a lot. I learnt new words, which I never knew before. I feel that I can explain better now.

Student 2: $\quad$ See what I missed out at high school. I looked up meaning of words. High school had no real exercises.

Student 3: $\quad$ It was good. It helped in writing. Expressed myself in writing what I thought and felt.

\section{How did you feel about writing in your journal?}

Student 1: $\quad$ At first I just started writing. I started writing nonsense. I couldn't think of what to write. Was challenging, was the first time to write in a journal.

Student 2: $\quad$ I felt good about writing in the journal. Sometimes I made sacrifices. Enjoyed writing, but at the same time anxious writing in a book that exposed myself. Wrote what I thought and felt. Had fun writing in the journal.

Student 3: $\quad$ It was good, helped me discover myself. Seeing it like a mirror. Re-read then surprised at how I felt.

\section{Have your ideas about expressive writing changed during this course?}

Student 1: $\quad$ Yes, now I write what I see. Used to think what was naturally, before people didn't get what I wanted to say.

Student 2: $\quad$ Yes, as a Xhosa speaking person normally speaking Xhosa, during that time to write in English or at least exposed myself in English

Student 3: $\quad$ Yes, there are different ways that you can write. Ways you can interpret things. Know now how to naturally express myself and that if someone reads it, know where I am coming from.

We can see from the responses of the students that there appears to be a perceived benefit to this form of writing, in that this form of writing helped the students discover themselves, as one of the students claimed. An intriguing response from Student 2 was that he felt that he had exposed himself, which in his culture he was not used to. In this sense, cultural identity takes shape and we learn that, in certain cultures, doing certain things is not acceptable.

I found that the data analysed in this article support my conceptualisation of learning to write, in which my students attempted to learn to write as a lived-through experience. Most importantly, they helped themselves to appreciate and believe the immediacy and primacy of the meanings and the knowledge that they created through the use of writing (Lantolf, 2000). In this respect, their writing has not only become 'their own' or 'authentic' but has also become 
a valuable creation in the context of study as it is 'eminently aesthetic' (Lantolf, 2000: 152) by virtue of being plausible and permeable in that they were exposing themselves to the public in their writing.

\section{DISCUSSION}

The general assumption of researchers on writing is that, in contrast to essay writing, creative writing provides a writing opportunity which permits students to tap into a much more private, personal emotional reality for their ideas and material (Canagarajah, 1999: 175). This is characterised by freedom from the non-personal, external demands of facts and other people's ideas, comments and forms. For the most part, writing is concerned with original, creative, personal experiences and feelings that can be discovered by the 'self' and that provide the basis for their material (Pfeiffer, 2015; Voit, 2009). At the same time, the students were appropriating the language 'on their own terms, according to their needs, values and aspirations' (Canagarajah, 1999: 175-176).

As a result, the elaborative processing evidenced in the journal entries and the absence of tension associated with linearity and conventional structures of discourse can help account for the meaning potential evident in the fluency of writing by the students (Pfeiffer, 2015; Voit, 2009). The journal entries point to the fact that this kind of writing exercises helped students recognise their identity and gave them a sense of belonging in society. This we see when Student 1 mentions in the second journal entry '... I know you become multilingual but I think its more fun and interesting when you speak you own language ...' Here, the student is aware that there are other languages but feels that speaking his own language is fun and interesting. Student 2 uses Afrikaans words to bring his point across, maybe even to sound funny when he says: 'Where I got the strength to ask that, "U weet allen" as the afrikaaners would say.' It appears that one of the greatest benefits of writing in a journal is that it may help students get over the fear that they may have of writing in a non-native language, which may lead to more self-confidence and a willingness to write. These benefits are also reported by Jones (1991) and Voit (2009).

The data from autobiographical writing revealed how the students were able to transcend the barriers that accuracy normally imposes on writers, through a fluency which they identified with as a motivating force. This is evident when the students are able to use conjunctions in their sentences for example: 'My life was not easy to be born without a father by myside. My mother was there for me yet I needed my father.' I found that their sentences were simple, yet there was a definite flow in the structure and it was logical, as seen here: 'In 2011, when I came in South Africa, my uncle gave me a gift and told me to be serious with my studies. He was doing his last year in the faculty of medecin in Lubumbashi. Tow month later my father called me, and asked me if I really love uncle Christian.' I am aware that the sentences are not perfect, but we are able to understand what the student is trying to say. The intention here was that the student was able to make themselves understood in their writing.

Accordingly, in the situation of heteroglossia, the dominant perspective, or one's own perspective, is itself defamiliarised in academic writing (Middendorf, 1992: 35). This happens because as a writer one is able to make oneself visible from the perspectives of others, as well as one's own. My understanding of what Middendorf (1992: 35) refers to is that writing appears to rupture the mythological relationship to language, showing the gap between words and their meanings. This may be viewed when students lean on their home language when they used words like 'trois' and 'medecin'. In academic writing, the students' perspective does become 
defamiliarised and they are not certain how to bring their views across clearly, but with the help of expressive writing this gap between the writer and audience is narrowed in that the student is able to express themselves in writing.

The data reflect that the students' responses in the second interview demonstrated their ability to recreate themselves in new spaces and adopt new identities by acknowledging that writing in journals was something that is not acceptable really in their culture, as seen when Student 2 mentioned: 'Enjoyed writing, but at the same time anxious writing in a book that exposed myself.' 'Yes, as a Xhosa speaking person normally speaking Xhosa, during that time to write in English or at least exposed myself in English.'

As seen in Pfeiffer and Sivasubramaniam (2016: 106), there is not one single right form of writing which promotes expressive writing, but an informed way of writing can be achieved by getting the students to use personal response writing tasks. This can help promote fluency in writing. This may be viewed in the journal entry and autobiographical writing when they awaken and mention very personal experiences. An example of this is when Student 1 writes: 'My life was not easy to be born without a father by myside. My mother was there for me yet I needed my father. Growing older without a male in our house becomes a big challenges to me.' Another example comes from Student 3: 'My name is Anonymous, born in DRC. I was born in a kingdom family, my father Anonymous was a kind in our village. He had 7 wives and my mother Anonymous known by the name of Anonymous.'

It appears that integrating personally and emotionally meaningful writing instruction allows L2 writers to reflect on their personal experiences and to extend their self-understanding in relation to the cultural, linguistic, and emotional factors (Chamcharatsri, 2013: 72). In light of this, I argue that, by allowing my students to write about their personal history, I would be encouraging them to embrace L2 writing as a platform to negotiate their identities, then 'to find power and legitimacy in the second language' (Park, 2013b; Pfeiffer, 2015).

\section{SHIFTING LENSES}

My students' act of writing, as the data have shown, reflects their identities as social beings. Just like Makalela (2014: 679) found in his study, the languaging experiences of the multilingual students in this study revealed features of the 21st century, 'which extend our understanding of identity construction in super-diverse contexts: fluidity, versatility and mobility.' As Makalela (2014: 679) argues, 'it is this type of mobility that allows students to navigate their coco (blended) universe, which refers to their heteroglossic way of knowing and making sense of the world.'

When multilingual students are given the freedom to tap into their emotions while performing an expressive writing task, such as journal entries, autobiographical writing or a writing task that expects a personal response, it can assist them in academic writing. Using journal entries which are not corrected, but glanced over on a regular basis, students are motivated to write in English, but at the same time they are given the freedom to write without paying attention to grammar, punctuation and sentence structure. Writing about things that make them feel comfortable and familiar will help build their confidence in writing. It appears that, once stability in writing has been established, it will be easier for students to move into academic writing because their confidence in writing has been developed. For this reason, students do need some guidance with the help of grammatical worksheets, which can assist them with sentence structure. It is important that the grammar worksheets need to have a good explanation 
and an example of the exercise as a way to help students to recap what they have learned at school.

In light of this, I surmise that students at first may feel afraid to write, but after some encouragement and experience 'writing in the non-threatening context about a subject matter they enjoy, will help develop confidence and a more open attitude toward writing' (Jones, 1991; Voit, 2009: 18). Therefore, I argue that any personal expression and reflection situated at the core of academic literacy practice enhances the real purpose for language learning and relates to 'widening one's experience resources and positioning oneself in a multicultural and multilingual world' (Hanauer, 2012: 10). Hence, learners use language to make sense of themselves and the world they live in (Hanauer, 2012; Park, 2013b). In addition, the students use the target language to increase their linguistic capital and sense of self (Makalela, 2015). Thus, I argue that expressive writing can improve students' academic writing.

\section{CONCLUSION}

My study aimed at encouraging my students to view their writing as personal constructions of meanings. They were supposed to try and use their journal entries and class assignments to operationalise their effective and emotive use of language. In light of this, one of the primary ways in which respect for and the maintenance of all languages in South Africa can be achieved in higher education is by creating spaces that enable students to use, draw on and develop their home languages in addition to acquiring English (Van der Walt \& Dornback, 2011). Thus, this may not only be of importance for language development, but also for issues of identity and belonging in society. Students should be granted space to use either their home language or other language in which they feel comfortable. The use of journal writing grants students that freedom to express themselves, even if it means mixing their home language with the language of instruction.

Having witnessed this heteroglossic, many-sided issue, these student writers seem aware that their position about this matter is, in fact, of only partial consequence and still evolving - one voice among many. Therefore, their writing is rarely certain, self-contained and monoglossic (Middendorf, 1992: 43). By changing their thinking about writing, they change their writing (Middendorf, 1992: 43). I am of the opinion that a love of writing takes time to manifest itself in students. My data point to the students' attempt at expressing themselves in writing. Therefore, educators have to recognise the importance of allowing students both space and time to 'construct deeper understandings and make sense of their bi/multilingual worlds' (Garcia, 2009: 45). By providing students with opportunities to construct their own stories, we can legitimise and validate their lived experiences and identities as valuable assets and resources in South Africa. I deduce that, as educators, we could also support students to negotiate their L2 learning processes in multilingual and multicultural contexts and provide them with space to generate authentic narratives that explore their own language and cultural learning experiences, both in their home countries and in their new learning environment (Makalela, 2015).

As educators, we should not only pay more attention to what our courses are doing to the way students think about writing, but also to the way we teach writing. With this kind of focus, we must begin at the very first stages of children's writing, both in school and at home. 


\section{REFERENCES}

BRAUN, V \& V CLARK. 2006. Using thematic analysis in psychology. Qualitative Research in Psychology, 3:77-101.

BRUMFIT, CJ \& RA CARTER. 1986. Oxford applied linguistics: Literature and language teaching. Oxford: Oxford University Press.

CADMAN, K. 1997. Thesis writing for international students: A question of identity? English for Specific Purposes, 16(1):3-14.

CANAGARAJAH, AS. 1999. Resisting linguistic imperialism in English teaching. Oxford: Oxford University Press.

CANAGARAJAH, AS. 2011. Codemeshing in academic writing: Identifying teachable strategies of translanguaging. Modern Language Journal, 95:401-417.

CHAMCHARATSRI, PB. 2013. Emotionality and second language writers: Expressing fear through narrative in Thai and English. L2 Journal, 5(1):59-75.

GARCIA, O. 2009. Bilingual education in the $21^{\text {st }}$ century. Chichester: Wiley-Blackwell.

GARCIA, O. 2011. From language garden to sustainable languaging: Bilingual education in a global world. Perspectives, 34(1):5-9.

GARVIN, RT. 2013. Researching Chinese history and culture through poetry writing in an ESL composition class. L2 Journal, 5(1):76-94.

GRAHAM, S \& KR HARRIS. 1989. Improving learning disabled students' skills at composing essays: Self-instructional strategy training. Exceptional Children, 56(3):201-214.

HANAUER, DI. 2012. Meaningful literacy: Writing poetry in the language classroom. Language Teaching, 45(1):105-115.

HARLKAU, L. 2002. The role of writing in classroom second language acquisition. Journal of Second Language Writing, 11:329-350.

HYLAND, K. 2002. Options of identity in academic writing. ELT Journal, 56(4):354-358.

IVANIC, R. 1998. Writing and identity: The discoursal construction of identity in academic writing. Philadelphia, PA: John Benjamins.

JANG, EE. 2008. A framework for cognitive diagnostic assessment. In CA Chapelle, YR Chung \& J Xu (Eds), Towards adaptive CALL: Natural language processing for diagnostic language assessment. Ames: Iowa State University.117-131.

JONES, P. 1991. The various benefits of dialogue journals. In JK Peyton \& JP Lantolf (Eds). 2000. Sociocultural theory and second language learning. Oxford: Oxford University Press.

KEATS, J. 1994. The complete poems of John Keats. London: Wordsworth.

LAPIDUS, A, Y KAVEH \& M HIRANO. 2013. ESL teachers/ ESL students: Looking at autoethnography through the lens of personetics. L2 Journal, 5(1):19-42.

LEA, M \& B STREET. 1999. Writing as academic literacies: understanding textual practices in higher education. In CN Candlin \& K Hyland (Eds), Writing: Texts, processes and practices. Essex: Addison Wesley. 62-81.

LEPPÄNEN, S, A PITKÄNEN, A PIIRAINEN-MARSH, T NIKULA \& S PEURONEN. 2009. Young people's translocal new media uses: A multiperspective analysis of language choice and heteroglossia. Journal of Computer-Mediated Communication, 14(4):10801107.

MAKALELA, L. 2013. Translanguaging in Kasi-taal: Rethinking old language boundaries for New Language Planning. Stellenbosch Papers in Linguistics Plus, 42:111-125.

MAKALELA, L. 2014. Fluid identity construction in language contact zones: Metacognitive reflections on Kasi-taal languaging practices. International Journal of Bilingual Education and Bilingualism, 17(6):668-682. 
MAKALELA, L. 2015. Translanguaging as a vehicle for epistemic access: Cases for reading comprehension and multilingual interactions. Per Linguam, 31(1):15-29.

MIDDENDORF, M. 1992. Bakhtin and the dialogic writing class. Journal of Basic Writing, 11(1):34-46.

MORRISON, T. 1987. Beloved. New York: Random House.

NUNN, R, S SUVASUBRAMANIAM, Y GUEFRACHI, A TARIQ \& H AL SHAMI. 2012. Establishing Voice and Agency in Students' Writing. In RS Sharda (Ed.), Proceedings of International Conference on English Language \& Literary Studies. 1-8.

PARK, G. 2013a. My autobiographical-poetic rendition: An inquiry into humanizing out teacher scholarship. L2, Journal, 5(1):6-18.

PARK, G. 2013b. 'Writing is a way of knowing': Writing and identity. ELT Journal, 67:336345.

PFEIFFER, V. 2015. An investigation of L2 expressive writing in a tertiary institution in the Western Cape. Unpublished doctoral thesis. University of the Western Cape, Cape Town.

PFEIFFER, V \& S SIVASUBRAMANIAM, 2016. Exploration of self-expression to improve L2 writing skills. Per Linguam, 32(2):95-108. http://dx.doi.org/10.5785/32-2-654

ROSENBLATT, L. 1978. The reader, the text, the poem: The transactional theory of the literary work. Carbondale, IL: Southern Illinois University Press.

Rosenblatt, L. 1995. Literature as exploration. New York: The Modern Language Association of America.

RUSSELL, G, S BAKER \& L EDWARDS. 1999. Teaching expressive writing to students with learning disabilities. Available from: http://www.Idonline.org/article/6201/?theme=print.[Accessed: 14 November 2016]

SPIGELMAN, C. 1996. Teaching expressive writing as a narrative fiction. JAC, 16:119-140.

VAN DER WALT, C \& J DORNBRACK. 2011. Academic biliteracy in South African higher education: strategies and practices of successful students. Language, Culture and Curriculum, 24(1):89-104.

VAN MANEN, M. 1990. Researching lived experience: Human science for an action sensitive pedagogy. Albany, NY: SUNY Press.

VOIT, M. 2009. Do dialogue journals with recasts improve the writing skills for adult learners with limited literacy skills? Unpublished master's dissertation. Hamline University, Saint Paul, MN. 
Addendum 1: Holistic grading scale used when marking autobiographical writing

\begin{tabular}{|c|c|}
\hline Rubric & Mark 20 \\
\hline $\begin{array}{l}\text { 1. The audience is able to easily identify the } \\
\text { focus of the work and is engaged by its clear focus } \\
\text { and relevant details. Information is presented } \\
\text { logically and naturally. Mechanical errors or } \\
\text { misspelled words do not distract the reader. }\end{array}$ & $20-15$ \\
\hline $\begin{array}{l}\text { 2. The audience is easily able to identify the } \\
\text { focus of the student work which is supported by } \\
\text { relevant ideas and supporting details. Information } \\
\text { is presented in a logical manner that is easily } \\
\text { followed. Minimal interruption to the work due to } \\
\text { misspellings and/or mechanical errors. }\end{array}$ & $14-10$ \\
\hline $\begin{array}{l}\text { T. The audience can identify the central } \\
\text { purpose of the student work without little } \\
\text { difficulty and supporting ideas are present and } \\
\text { clear. The information is presented in an orderly } \\
\text { fashion that can be followed with little difficulty. } \\
\text { There are some misspellings and/or mechanical } \\
\text { errors, but they do not seriously distract from the } \\
\text { work. }\end{array}$ & $9-5$ \\
\hline $\begin{array}{l}\text { The audience cannot clearly or easily } \\
\text { identify the central ideas or purpose of the student } \\
\text { work. Information is presented in a disorganized } \\
\text { fashion causing the audience to have difficulty } \\
\text { following the author's ideas. There are many } \\
\text { misspellings and/or mechanical errors that } \\
\text { negatively affect the audience's ability to read the } \\
\text { work. }\end{array}$ & $4-0$ \\
\hline
\end{tabular}

